\title{
Vírus da leucemia felina: análise da classificação da infecção, das técnicas de diagnóstico e da eficácia da vacinação com o emprego de técnicas sensíveis de detecção viral
}

\author{
Feline leukemia virus: infection outcomes, diagnostic techniques and vaccine efficacy analysis employing \\ sensitive techniques of virus detection
}

\author{
Andreza Soriano Figueiredo ${ }^{\mathrm{F}^{*}}$ João Pessoa Araújo Júnior ${ }^{\mathrm{I}}$
}

\section{-REVISÃO BIBLIOGRÁFICA-}

\section{RESUMO}

O Vírus da leucemia felina (FeLV) pertence à família Retroviridae, gênero Gammaretrovirus. Diferentemente de outras retroviroses, uma parcela dos gatos jovens e adultos exposta ao FeLV não apresenta antigenemia/viremia, de acordo com as técnicas convencionais de detecção viral, como isolamento em cultivo celular, imunofluorescência direta e ELISA. O emprego de técnicas de maior sensibilidade para detecção e quantificação viral, como o PCR quantitativo, permitiu a identificação de animais positivos para a presença de DNA proviral e RNA na ausência de antigenemia/viremia e, com isso, um refinamento da análise das diferentes evoluções da infecção. Assim, reclassificou-se a patogenia do FeLV em 4 categorias: infecção abortiva, regressiva, latente e progressiva. Foi possível também detectar DNA proviral e RNA em animais considerados imunes ao FeLV após vacinação. Diante disso, os objetivos desta revisão de literatura foram demonstrar as implicações da utilização de técnicas sensíveis de detecção viral na interpretação e classificação da infecção do FeLV e rever as técnicas de detecção do vírus para fins de diagnóstico. Além disso, apresentar os resultados referentes à eficácia da vacinação contra o FeLV com a utilização dessas técnicas.

Palavras-chave: antigenemia, viremia, patogenia, PCR quantitativo, vacinação, FeLV.

\footnotetext{
ABSTRACT

Feline leukemia virus (FeLV) belongs to the Retroviridae family, genus Gammaretrovirus. Unlike other retroviruses, a portion of FeLV exposed animals eliminates antigenemia/viremia, according to convectional techniques of virus detection, such as isolation in cell culture, direct fluorescent antibody test and ELISA. The use of more sensitive techniques to detect and quantify viruses enabled the detection of proviral DNA and RNA in cats with undetectable antigenemia/viremia,
}

and thus the refinement of the different infection outcomes analysis. As a result, FeLV pathogenesis was reclassified in 4 categories: abortive, regressive, latent and progressive infections. It was also demonstrated the detection of proviral DNA and RNA in cats believed to be immune to infection after vaccination. Therefore, the objectives of this review were to demonstrate the implications of the use of sensitive techniques for viral detection in the interpretation and classification of FeLV infection and reconsider the techniques for FeLV diagnostic purposes. In addition, it was presented the results concerning the effectiveness of FeLV vaccination with the use of these techniques.

Key words: antigenemia, viremia, pathogenesis, quantitative $P C R$, vaccination, FeLV.

\section{INTRODUÇÃO}

O Vírus da leucemia felina (FeLV) foi descrito em 1964 por William Jarrett e colaboradores ao encontrarem partículas virais ligadas à membrana de linfoblastos em um gato com linfoma (JARRET et al., 1964). O FeLV pertence à família Retroviridae, gênero Gammaretrovirus. O vírus possui envelope lipoprotéico e material genético RNA fita simples. O RNA é transcrito em DNA (provírus) pela RNA polimerase viral Transcriptase reversa (RT) e é integrado ao genoma celular. O provírus contém sequências repetidas (Long Terminal Repeat - LTR) nas extremidades 5' e 3', com função regulatória e de controle da expressão dos genes virais. Entre as LTRs, encontram-se os genes gag, pol e env. O gene gag

'Departamento de Microbiologia e Imunologia, Instituto de Biociências, Universidade Estadual Paulista (UNESP), Distrito de Rubião Júnior, S/N, 18618-970, Botucatu, São Paulo, Brasil. E-mail: andrezasofi@gmail.com. *Autor para correspondência. 
codifica proteínas estruturais internas (p15c, p12, p27 e p10), o gene pol codifica proteínas envolvidas na replicação viral (Integrase, RT) e o gene env codifica proteínas do envelope viral (gp70 e p15e) (HARTMANN, 2006).

O FeLV e o Vírus da imunodeficiência felina (FIV) são retrovírus exógenos, transmitidos horizontalmente entre gatos, ao contrário dos retrovírus endógenos que são sequências de DNA proviral no genoma celular, transmitidas pela linhagem germinativa, como os vírus RD-114, enFeLV e MAC-1 (HARTMANN, 2006).

O FeLV é classificado em quatro subgrupos, FeLV-A, B, C e T, identificados geneticamente de acordo com diferenças no gene da SU e, funcionalmente, pela utilização de diferentes receptores para entrada na célula hospedeira (OVERBAUGH \& BANGHAM, 2001).

Somente o subgrupo Aé transmissível entre gatos (JARRETT et al., 1984). A proteína de membrana hospedeira utilizada como receptor é a Feline highaffinity thiamine transporter 1 (feTHTR1),encontrada em tecidos de absorção como intestino delgado, fígado e rins, e também em células do sistema linfóide (MENDOZA et al., 2006). Essa ampla distribuição é consistente com o fato de que o FeLV-A é encontrado nesses diversos tecidos e células (HOOVER et al., 1977) e pode explicar a vantagem sobre os outros subgrupos no que diz respeito à transmissibilidade. Esse subgrupo pode causar linfomas, mas geralmente promove lesões moderadas na ausência de outros subgrupos (MOSER et al., 1998). O FeLV-B é comumente associado a linfomas (JARRETT et al., 1973; HARTMANN, 2006). Esse variante surge da recombinação entre FeLV-A e sequências retrovirais endógenas e, portanto, compartilha a menor identidade entre sequências (STEWART et al., 1986). O subgrupo C é o mais patogênico, causa anemia aplástica e surge a partir de mutações na sequência da SU do FeLV-A (HARDY et al., 1976). O FeLV-T foi originalmente isolado de um gato com FeLV induced immunodeficiency (FAIDS). Esse subgrupo apresenta aproximadamente $96 \%$ de similaridade com o subgrupo A e surge a partir de mutações na sequência do gene da SU do FeLV-A (DONAHUE et al., 1991). De acordo com HARDY et al. (1976), em 100\% dos animais infectados, foi detectado o FeLV-A. Em 49\% detectou-se coinfecção com o FeLVB e em $1 \%$ com o FeLV-C.

A prevalência da infecção é de difícil determinação, uma vez que a realização dos testes de diagnóstico é voluntária e, pela ausência de um órgão central de coleta de dados (LEVY et al., 2006), os dados encontrados no Brasil apresentam grande variação. Foram encontrados 12,6\% (BARBOSA et al., 2001),
32,5\% (TEIXEIRA et al., 2007) e 47,5\% (COELHO et al., 2008) de amostras positivas no Estado de Minas Gerais. MEINERZ et al. (2010) encontraram 38,3\% no Rio Grande do Sul e SOUZA et al. (2002) encontraram 17,4\% no Rio de Janeiro. HAGIWARA et al. (2007) e FIGUEIREDO et al. (2009), em estudos com abrangência de diversos Estados brasileiros, encontraram 6,2\% e $5,3 \%$, respectivamente. Essas variações podem ser explicadas pela análise de diferentes grupamentos de animais, já que animais com acesso à rua têm quase três vezes mais probabilidade de adquirir o vírus do que animais de acesso restrito (MEINERZ et al., 2010). O contato permanente com gatos de rua ou a introdução de animais de grupamentos infectados pelo FeLV facilita a disseminação do vírus (HARDY et al., 1973; HAGIWARA et al., 1997).

Outra consideração importante com relação à prevalência da infecção do FeLV é o emprego de diferentes métodos de diagnóstico (TEIXEIRA et al., 2007; COELHO et al., 2008). No estudo conduzido por COELHO et al. (2008), por exemplo, foi encontrada uma elevada porcentagem de positividade para o FeLV (47,5\%), sendo atribuída ao emprego de um método de diagnóstico de maior sensibilidade, que detecta animais numa fase que outros testes não detectam.

Historicamente, o diagnóstico da infecção pelo FeLV era realizado com: (1) antigenemia com detecção de antígeno extracelular por Enzyme Linkedimmunosorbent Assay (ELISA) (proteína de capsídeo p27) (LUTZ et al., 1983), (2) antigenemia com detecção de antígeno intracelular por imunofluorescência direta (HARDY et al., 1973) e (3) viremia por isolamento em cultivo celular (FISCHINGER et al., 1974).

O ELISA baseia-se na detecção da proteína de capsídeo de $27 \mathrm{kDa}$ (p27) no soro ou plasma, onde é encontrada em abundancia em animais infectados, constituindo-se bom marcador para detecção da infecção (LUTZ et al., 1983). O teste detecta animais positivos a partir da quarta semana após infecção (JARRET et al., 1982; FLYNN et al., 2002) e é recomendado como teste de triagem (LEVY et al., 2008; LUTZ et al., 2009).

O teste de imunofluorescência direta (IFA) é baseado na observação de que, em animais virêmicos, os granulócitos, linfócitos e plaquetas contêm componentes do gene gag que podem ser detectados por anticorpos específicos em esfregaço sanguíneo (HARDY et al., 1973). Entretanto, a IFA não constitui bom teste de triagem, pois a detecção dos antígenos intracelulares não coincide com o aparecimento da p27 no soro ou plasma (LUTZ et al., 1980).

O isolamento viral foi o teste originalmente desenvolvido para identificação de gatos infectados 
(FISCHINGER et al., 1974). Uma vez que ele detecta vírus infectivos, o isolamento em cultivo celular é considerado teste definitivo, entretanto, não é praticado na rotina pela complexidade de sua realização (LUTZ et al., 2009).

Esses mesmos testes eram utilizados para a interpretação e a classificação das diferentes fases da infecção, sendo possível a determinação de três categorias: infecção regressiva e infecção latente pela montagem de uma resposta imune efetiva e infecção progressiva no caso de uma resposta imune deficiente (ROJKO et al., 1979; HARTMANN, 2006). Uma vez que uma resposta imune efetiva dos animais era capaz de eliminar a infecção, ocorreram grandes investimentos para o desenvolvimento da primeira vacina considerada efetiva contra retrovírus (LEWIS, 1981; SPARKES, 1997). Entretanto, recentemente, o emprego de testes de maior sensibilidade para deteç̧ão e quantificação viral permitiu o encontro de resultados discrepantes.

Os objetivos desta revisão de literatura foram discorrer sobre as implicações da utilização de técnicas sensíveis de deteç̧ão viral na interpretação e classificação das diferentes fases da infecção do FeLV e rever os métodos empregados para fins de diagnóstico. Além disso, apresentar os resultados das análises de eficácia da vacinação contra o FeLV com o emprego dessas técnicas.

Patogenia do FeLV com o emprego de técnicas convencionais de detecção viral

Até 2005, as diferentes evoluções patológicas desencadeadas pelo FeLV eram categorizadas com base na viremia por isolamento em cultivo celular, antigenemia com detecção de antígeno intracelular por imunofluorescência direta ou antigenemia com deteç̧ão de antígeno extracelular por ELISA de captura (p27) (TORRES et al., 2010). De acordo com esses parâmetros, após exposição oronasal, a infecção era classificada como:

infecção regressiva - Ocorre a replicação viral nas tonsilas e linfonodos regionais (ROJKO et al., 1979), o animal desenvolve resposta imune efetiva contra o vírus e este é eliminado. Não ocorre disseminação sistêmica e a antigenemia/viremia é indetectável (LUTZ et al., 1980; TORRES et al., 2010). Se o animal não desenvolve imunidade adequada, o vírus é disseminado sistemicamente por linfócitos e monócitos. A antigenemia/viremia é transiente, pois é detectável por cerca de três a seis semanas, ocorrendo completa eliminação do vírus após esse período (LUTZ et al., 1980; FLYNN et al., 2000; FLYNN et al., 2002);

infecção latente - $\mathrm{O}$ animal apresenta antigenemia/ viremia por mais de três semanas e ocorre infecção de células da medula óssea (ROJKO et al., 1979; HARTMANN, 2006). Dentro de meses, o animal desenvolve uma resposta imune capaz de eliminar a antigenemia/viremia, mas o DNA proviral está presente nas células precursoras da medula. Essa fase é identificada apenas por cultivo de células de medula óssea (HARTMANN, 2006);

infecção persistente - Em animais com sistema imune incapaz de eliminar a antigenemia/viremia após 4 a 6 semanas de infecção, ocorre a disseminação viral para tecidos glandulares e epiteliais, incluindo glândulas salivares e as mucosas nasal e faringeal (SPARKES, 1997). A infecção desses tecidos permite a eliminação do vírus ao ambiente e a possível transmissão horizontal (HARDY et al., 1973; SPARKES, 1997). Animais com infecção persistente sucumbem às doenças associadas ao FeLV e a maioria morre dentro de três anos (HARTMANN, 2006; LEVY et al., 2008).

De acordo com as técnicas mencionadas, foi possível estimar que, aproximadamente, $60 \%$ dos animais adultos jovens expostos ao FeLV eliminavam a infecção, pois não eram detectados antígeno p27 e vírus infectivo. Aproximadamente, $30 \%$ dos animais desenvolviam antigenemia e viremia persistentes. Entre 5 a $10 \%$ dos animais apresentavam infecção atípica com a replicação viral restrita em alguns tecidos como glândula mamária, baço e linfonodos. Nesses casos, a antigenemia era intermitente, alternando resultados positivos e negativos nos testes de detecção da p27 (HOOVER \& MULLINS, 1991).

Patogenia do FeLV com o emprego de técnicas sensíveis de detecção viral

A utilização das técnicas de deteçãao do antígeno p27 e isolamento viral resultou na identificação de resultados conflitantes. Parte dos animais que apresentava sinais clinicopatológicos compatíveis com a infecção mostrava ser FeLV- negativa (TORRES et al., 2010). Antígeno viral (p27) circulante estava presente em cerca de $70 \%$ dos animais com anemias não regenerativas, $88 \%$ com doenças mieloproliferativas (excluindo linfossarcoma), 70\% com linfossarcoma e 80\% com doenças mielodegenerativas (HARDY, 1981). Adicionando-se relatos de que foi possível reativar a infecção em animais considerados regressores (MADWELL\& JARRETT, 1983), no final da década de 90, tanto a classificação das diferentes evoluções patológicas do FeLV e a sensibilidade dos testes empregados foram questionadas (TORRES et al., 2010).

Em 1996, JAKSON et al. propuseram que a PCR, uma técnica de maior sensibilidade, detectaria DNA proviral nas amostras de animais com sinais clinicopatológicos altamente sugestivos da infecção 
pelo FeLV, mas que apresentavam resultado negativo para antígeno p27. No entanto, não foi encontrada nenhuma diferença entre os resultados do ELISA e a PCR. Já em 2001, HOFMANN-LEHMANN et al. empregaram uma técnica de maior sensibilidade, especificidade e rendimento (GUNSON et al., 2006), a qPCR, para detectar DNA proviral, sendo os primeiros a relatar resultados contraditórios entre a PCR e o ELISA. Dez por cento de 597 amostras foram negativas por ELISA, mas positivos por PCR; dois animais, experimentalmente infectados, foram negativos por ELISA, mas positivos por PCR já na primeira semana após infecção; e animais com antigenemia transiente permaneceram positivos por PCR mesmo após a eliminação da antigenemia.

Em 2005, TORRES et al. empregaram a qPCR para a quantificação de DNA proviral nos estágios iniciais e avançados da infecção comparando-se com dados obtidos com o teste para antígeno p27. De acordo com os resultados, os autores incluíram mais uma categoria na classificação das diferentes evoluções patológicas desencadeadas pelo FeLV. Animais que foram negativos para a presença da p27 e negativos para DNA proviral foram classificados como em Infecção Abortiva. Animais p27 negativos, mas positivos para DNA proviral foram classificados em Infecção Regressiva. Animais positivos para p27 e DNA proviral durante a segunda e quarta semanas após infecção, mas p27 negativos e DNA positivos após a sexta semana foram considerados em Infecção Latente. Animais p27 e DNA proviral positivos durante todo o período do experimento foram considerados em Infecção Progressiva.

Segundo essa classificação, os animais expostos ao FeLV que não apresentaram antigenemia foram capazes de eliminar o vírus antes mesmo que ocorresse a integração ao genoma hospedeiro (Infecção Abortiva) ou contiveram a replicação viral mantendo células infectadas não produtivas na circulação e em tecidos (Infecção Regressiva). A reativação da replicação nessas células seria possível. Animais com menor capacidade de conter a progressão da infecção apresentaram antigenemia somente nas primeiras semanas e níveis moderados (distinguíveis dos outros grupos) de DNA proviral (Infecção Latente). As células infectadas estariam em latência, mas seriam potencialmente produtivas. A reativação da replicação seria mais esperada nesses casos. Os animais incapazes de conter a progressão da infecção apresentaram os níveis mais elevados de p27 e DNA proviral até três anos após exposição (Infecção Progressiva) (TORRES et al., 2005)

Mais tarde, HOFMANN-LEHMANN et al. (2007), empregando ensaios ainda mais sensíveis, demonstraram resultados um pouco diferentes e classificaram os animais com antigenemia indetectável ou transiente e níveis moderados de DNA proviral em Infecção Regressiva. Já a Infecção Latente foi caracterizada como a presença de antigenemia transiente, mas com níveis de DNA proviral indistinguíveis dos animais em infecção regressiva.

É importante ressaltar que os resultados obtidos a partir das pesquisas com técnicas sensíveis de quantificação viral permitiram confirmar a correlação positiva entre quantidade de DNA proviral inicial (sangue) e a progressão da infecção, sendo possível detectar o DNA proviral já na primeira semana após infecção. Entretanto, somente a partir da terceira semana, é que a quantidade de DNA proviral foi significativamente diferente entre animais que evoluíram para Infecção Regressiva ou para Infecção Progressiva (HOFMANN-LEHMANN et al., 2001) o que sugere que, com a qPCR, é possível diagnosticar a infecção antes que seja possível detectar antígeno p27 circulante, no entanto, neste estágio ainda não será possível prever o prognóstico da infecção.

Nesse contexto, TANDON et al. (2005) sugeriram que a quantificação do RNA viral por PCR (RT-qPCR) nas primeiras semanas após infecção seria uma ferramenta para compreensão da interação vírus/ hospedeiro neste período em que o sistema imune é inicialmente confrontado pelo FeLV. Além disso, poderia detectar a infecção nos casos em que o FeLV encontrase confinado em determinados tecidos, quando somente o RNA pode ser encontrado na circulação.

O RNA viral foi detectado já na primeira semana após infecção experimental, entretanto, os níveis encontrados foram semelhantes entre animais com antigenemia indetectável, transiente e persistente. Somente após a segunda semana, os níveis de RNA viral foram distinguíveis de acordo com o curso da infecção (HOFMANN-LEHMANN et al., 2007). Nesse caso, o diagnóstico também pode ser realizado na primeira semana após infecção e o prognóstico pode ser discutido já na segunda semana. Entretanto, a instabilidade natural do RNA e a etapa de conversão de RNA em DNA complementar (cDNA) contribuem para a ausência de reprodutibilidade frequentemente encontrada nas reações de RT-qPCR (BUSTIN et al., 2005).

Assumia-se então que, excluindo-se animais com infecção abortiva, todos os animais seriam positivos para DNA proviral e RNA viral. Entretanto, se a presença de RNA viral indica replicação ativa, como explicar o fato de não se detectar antígeno p27 nem vírus infectivo, por exemplo, em animais classificados como em infecção regressiva? TORRES et al. (2010) 
sugeriram que haveria produção de antígeno e vírions abaixo dos limites de detecção dos testes.

Em conjunto, os dados obtidos a partir das análises de quantificação de DNA proviral, RNA viral, antigenemia (p27) e isolamento viral permitiram a HOFMANN-LEHMANN et al. (2008) sugerirem a seguinte classificação:

infecção abortiva - ausência de DNA proviral, RNA viral, antígeno p27 e isolamento após contato; infecção regressiva: níveis moderados de DNA proviral e RNA viral com antigenemia indetectável ou transiente. $\mathrm{O}$ DNA proviral é detectável ao longo da infecção, mas o RNA viral pode ou não ser detectado; infecção progressiva: níveis elevados de DNA proviral e RNA viral, antigenemia e isolamento viral constantes.

Para a infecção latente, foi mantida a definição anterior, sendo a ausência de antigenemia/ viremia e persistência de vírus com potencial de reativação na medula óssea (HOFMANN-LEHMANN et al., 2008). Essa recomendação deveu-se à obtenção de resultados conflitantes: enquanto um grupo encontrou níveis distinguíveis dos outros grupos de DNA proviral (TORRES et al., 2005), outro grupo encontrou níveis equivalentes à categoria de animais com infecção regressiva (TANDON, et al., 2005).

A importância clínica de animais antígeno p27 negativos, mas DNA proviral positivos permanece desconhecida. Seria possível a reativação da infecção e transmissão do FeLV a partir de animais em infecção regressiva, latente ou mesmo com infecção restrita em determinados tecidos?

A reativação da infecção, apesar de rara, foi relatada. Em 2007, HOFMAN-LEHMANN et al. demonstraram o primeiro caso de reativação da infecção pela detecção de antigenemia e aparecimento de doenças associadas ao FeLV um ano após infecção experimental. Destaca-se que tanto o DNA proviral e o RNA viral foram persistentemente detectados. Recentemente, em 2010, HELFER-HUNGERBUEHLER et al. demonstraram a detecção de DNA proviral em todas as amostras colhidas durante 8,5 anos de acompanhamento de um animal experimentalmente infectado com FeLV (classificado em infecção regressiva) e o Vírus da imunodeficiência felina (FIV). Concomitantemente com o estabelecimento da imunossupressão causada pelo FIV, ocorreu a reativação da infecção do FeLV e só então foi possível detectar antígeno p27 e os níveis de DNA proviral elevaram. Em nenhum dos estudos, investigou-se a presença de RNA ou DNA proviral em tecidos como glândula mamária e baço. TORRES et al. (2010) especulam que a transmissão pelo leite ou plasma é possível.
Os resultados não apenas sugerem novas interpretações e classificações, mas também implicam rever as formas de detecção do FeLV para fins de diagnóstico. A American Association of Feline Practitioners (AAFP) (LEVY et al., 2008) e o European Advisor Board on Cat Diseases (ABCD) (LUTZ et al., 2009) recomendam que o diagnóstico de FeLV deva ser realizado com teste de triagem pela detecção de antígeno por ELISA, sendo todo resultado positivo confirmado com um segundo teste, após um período de um mês, para antígeno p27 ou DNA proviral por PCR. No entanto, recomendamos o emprego da PCR para diagnóstico, disponibilizado por laboratório de confiança, uma vez que detecta DNA proviral na primeira semana após infecção. O teste de detecção de antígeno p27 deve ser empregado juntamente com a PCR, já que a presença do antígeno circulante pode ajudar no estabelecimento do prognóstico da infecção.

Vacinação

Devido à aparente capacidade de gatos domésticos em conter o avanço da infecção, muitos investimentos foram realizados para o desenvolvimento de vacinas contra o FeLV. O objetivo principal era estabelecer um modelo animal para as pesquisas com outros retrovírus, em destaque, o Vírus da imunodeficiência humana (HIV) (HANLON et al., 2001). Diversas vacinas em diferentes formatos foram desenvolvidas, mas comparar os resultados de eficácia sempre foi motivo de discussão, principalmente, pelo emprego de diferentes vias de inoculação, cepas virais e amostragens (SPARKES, 1997; LUTZ et al., 2009).

As descobertas em 2001 e 2002 de que animais expostos ao FeLV com infecção regressiva apresentaram DNA proviral colocaram em dúvida a proteção imune induzida pelas vacinas contra o FeLV sob o ponto de vista das técnicas utilizadas para determinação da eficácia das vacinas (TORRES et al., 2005). Em 2005, TORRES et al. avaliaram a eficácia de vacinas empregando a qPCR. A eficácia da vacina FelO-Vax Lv-K (Fort Dodge Animal Health) foi similar à encontrada em outros estudos, no entanto, houve a detecção de DNA proviral em animais considerados protegidos pela vacina. Em 2006, HOFMANNLEHMANN et al. avaliaram as vacinas Eurifel (Merial) e Fel-O-Vax Lv-K IV (Fort Dodge Animal Health) e, em 2007, a vacina Leucogen (Virbac). Em ambos os estudos, foram detectados DNA proviral e RNA viral em todas as amostras de animais vacinados após desafio e, mesmo durante dois anos de acompanhamento, o DNA proviral foi detectado em todos os animais, permitindo concluir que as vacinas não impedem a integração viral e mínima replicação. 
A presença viral, até então indetectável pelos métodos convencionais, em animais vacinados pode ser importante para o estabelecimento de uma sólida imunidade com uma constante indução da resposta específica, entretanto, o termo "imunidade esterilizante contra infecções retrovirais" não pode ser empregado (HOFMANN-LEHMANN et al., 2006).

Em 2010, TORRES et al. demonstraram o maior nível de proteção dentre os estudos de eficácia de vacinas que empregaram a qPCR. As três vacinas: (i) Fel-O-Vax Lv-K (Fort Dodge Animal Health) e (ii) FEVAXYN FeLV (Shering-Plough Animal Health Corporation), compostas de vírus inativado, e (iii) LEUKOCELL 2 (Pfizer Animal Health), composta de subunidades aprovadas pelo United States Department of Agriculture (USDA) (TORRES et al., 2010) e que, na época, eram também aprovadas pelo Ministério da Agricultura, Pecuária e Abastecimento (MAPA) (COORDENAÇÃO DE FISCALIZAÇÃO DE PRODUTOS VETERINÁRIOS, 2010), foram avaliadas. Somente aquelas compostas de vírus inativado induziram imunidade suficiente para garantir resistência à antigenemia/viremia e à infecção, verificada pela não detecção de antígeno p27, vírus infectivo, DNA proviral e RNA viral após desafio.

É importante ressaltar que a vacina Fel-OVax Lv-K IV, apesar de conter outros quatro antígenos, possui a mesma constituição de antígenos de FeLV que a vacina Fel-O-Vax Lv-K. Entretanto, os resultados dos estudos de eficácia destas vacinas foram contraditórios entre HOFMANN-LEHMANN et al. (2006 e 2007) e TORRES et al. (2010). Fica evidente, dessa forma, que estudos comparativos de eficácia de vacinas podem levar a interpretações errôneas e que a padronização dos métodos é de extrema importância.

Dentre as vacinas analisadas, apenas a vacina LEUKOCELL 2 possui licença vigente para ser comercializada no Brasil (COORDENAÇÃO DE FISCALIZAÇÃO DE PRODUTOS VETERINÁRIOS, 2011). Para essa vacina, a Fração de prevenção, valor que indica a porcentagem de animais protegidos pela vacinação, determinada com o emprego de técnicas convencionais, foi de 44,6\% (TIZZARD \& BASS, 1991) e 100\% (LAFRADO, 1994). Com a qPCR, a Fração de prevenção foi de $57 \%$, contra $100 \%$ da Fel-O-Vax Lv-K e FEVAXYN FeLV (TORRES et al., 2010). Segundo a American Association of Feline Practitioners (LEVY et al., 2008) e o European Advisor Board on Cat Diseases (ABCD) (LUTZ et al., 2009), nenhuma vacina promove $100 \%$ de proteção e não previne a infecção, no entanto, a vacinação previne o desenvolvimento de antigenemia persistente. Assim, animais vacinados são menos propensos a desenvolver doenças associadas ao FeLV e têm maior sobrevida (HOFMANNLEHMANN et al., 2008). Independentemente da vacina utilizada, a indicação é que filhotes devem receber a primeira dose a partir da oitava semana de vida e a segunda após 4 semanas. O reforço deve ser anual. A vacinação não é obrigatória (LEVY et al., 2008; LUTZ et al., 2009) e as vacinas não interferem nos testes de diagnóstico (HARTMANN, 2006), assim, a decisão de se vacinar ou não deve ser tomada considerando-se, principalmente, o estilo de vida do animal. Animais com acesso à rua ou que vivem em abrigos com rotatividade de animais devem ser vacinados.

\section{CONCLUSÃO}

O emprego de técnicas de amplificação e quantificação de ácidos nucléicos, a qPCR e a RTqPCR, permitiram um refinamento da análise e classificação da evolução patológica desencadeada pela infecção do FeLV por serem mais sensíveis que as técnicas de detecção de antígeno e isolamento viral. Considerava-se anteriormente que gatos jovens e adultos eram capazes de eliminar a infecção pelo FeLV por não apresentarem antígeno viral circulante/ intracelular ou por não ser possível o isolamento viral. Entretanto, foi possível detectar DNA proviral e/ou RNA viral nesses animais. Nesse sentido, o impacto desses animais na disseminação do vírus ou mesmo para compreender a evolução da infecção permanece um desafio.

A partir dos dados apresentados, pode-se sugerir que o diagnóstico da infecção deve ser realizado em duas ou mais etapas, sendo preferível utilizar a PCR seguida de teste de detecção de antígeno p27. Além disso, as vacinas não impedem a integração e a mínima replicação viral, pois os animais vacinados apresentam DNA proviral e RNA após desafio e, portanto, as técnicas sensíveis de detecção viral ajudarão nos estudos de eficácia de vacinas.

\section{REFERÊNCIAS}

BARBOSA, F.C. et al. Prevalência da leucemia felina em gatos domésticos de Uberlândia - MG. Arquivo ciência veterinária e zoologia. UNIPAR, v.5, n.2, p.207-211, 2001.

BUSTIN, S.A. et al. Quantitative real-time RT-PCR - a perspective. Journal of Molecular Endocrinology, v.34, p.597-601, 2005. Disponível em: <http://www.endocrinologyjournals.org>. Acesso em: 05 mar. 2006. doi: 10.1677/ jme.1.01755.

COELHO, F.M. Naturally occurring feline leukemia virus subgroup A and B infections in urban domestic cats. Journal of General Virology, v.89, p.2799-2805, 2008. 
COORDENAÇÃO DE FISCALIZAÇÃO DE PRODUTOS VETERINÁRIOS. Relatório de produtos com licença vigente. Disponível em: <http://www.agricultura.gov.br/pls/portal/docs/ PAGE/MAPA/SERVICOS/CPV_NOVO/PRODUTOS_USO_VET/ RELA\%C7\%C3O\%20DE\%20PRODUTOS\%20COM\%20REGISTRO.PDF2010-09-02.PDF>. Online. Acesso em: 06 set. 2010.

COORDENAÇÃO DE FISCALIZAÇÃO DE PRODUTOS VETERINÁRIOS. Relatório de produtos com licença vigente. Disponível em: <http://www.agricultura.gov.br/portal/pls/portal/ !PORTAL.wwpob_page.show?_docname=72241.PDF>. Online. Acesso em: 09 maio, 2011.

DONAHUE, P.R. et al. Viral genetic determinants of T-cell killing and immunodeficiency disease induction by the feline leukemia virus FeLV-FAIDS. Journal of Virology, v.65, p.4461-4469, 1991. Disponível em: 〈http://jvi.asm.org>. Acesso em: 12 maio, 2010.

FIGUEIREDO, A.S. et al. Feline retrovirus (FIV and FeLV) infection and the susceptibility of secondary infection with Haemoplasmas. In: ENCONTRO NACIONAL DE VIROLOGIA, 20., 2009, Brasília, DF. Virus Reviews and Research, Journal of Brazilian Society for Virology. São Paulo: Imprinta Expressa, 2009. V.14, supl.1, p.88-89.

FISCHINGER, P.J. et al. Simple, quantitative assay for both xenotropic murine leukemia and ecotropic feline leukemia viruses. Journal of Virology, v.14, n.1, p.177-179, 1974.

FLYNN, J.N. et al. Feline leukaemia virus: protective immunity is mediated by virus-specific cytotoxic $\mathrm{T}$ lymphocytes. Immunology, v.101, p.120-125, 2000.

FLYNN, J.N. et al. Longitudinal analysis of feline leukemia virus-specific cytotoxic $\mathrm{T}$ lymphocytes: correlation with recovery from infection. Journal of Virology, v.76, p.23062315, 2002. Disponível em: 〈http://jvi.asm.org>. Acesso em: 25 fev. 2010. doi: 10.1128/JVI.76.5.2306-2315.2002.

GUNSON, R.N. et al. Practical experience of high throughput real time PCR in routine diagnostic virology setting. Journal of Clinical Virology, v.35, p.355-367, 2006. Disponível em: <http://www.elsevier.com/locate/jev>. Acesso em: 07 ago. 2007. doi: $10.1016 /$ j.jcv.2005.12.006.

HAGIWARA, M.K. et al. Estudo clínico da infecção de felinos pelo vírus da leucemia felina em São Paulo. Revista Brasileira de Ciências Veterinárias, v.4, p.35-38, 1997.

HAGIWARA, M.K. et al. Infecção pelo vírus da leucemia felina em gatos de diversas cidades do Brasil. Clínica Veterinária, n.66, p.44-50, 2007.

HANLON, L. et al. Feline leukemia vírus DNA vaccine efficacy is enhanced by coadministration with interleukin-12 (IL-12) and IL-18 expression vectors. Journal of Virology, v.75, n.18, p.8428-8433, 2001. Disponível em: 〈http://www.jvi.asm.org〉. Acesso em: 24 jun. 2010. doi: 10.1128/JVI.75.18.84248433.2001 .

HARDY, W.D. et al. Horizontal transmission of feline leukemia virus. Nature, v.244, p.266-269, 1973.

HARDY, W.D. Jr. et al. Biology of feline leukemia virus in the natural environment. Cancer Research, v.36, p.582-588, 1976.
HARDY, W.D. Jr. Feline leukemia virus non-neoplastic diseases. Journal of American Animal Hospital Association, v.17, p. 941-949, 1981.

HARTMANN, K. Feline leukemia virus infection. In: GREENE, C.E. Infectious disease of the $\mathrm{dog}$ and cat. 3.ed. Georgia: Elsevier, 2006. Cap.13, p.105-131.

HELFER-HUNGERBUEHLER, K. ET AL. Dominance of highly divergent feline leukemia virus A progeny variants in a cat with recurrent viremia and fatal lymphoma. Retrovirology, v.7, p.1-14, 2010. Disponível em: <http://www.retrovirology.com/ content/7/1/14>. Acesso em: 10 jun. 2010 .

HOFMANN-LEHMANN, R. ET AL. Feline leukaemia provirus load during the course of experimental infection and in naturally infected cats. Journal of General Virology, v.82, p.15891596, 2001.

HOFMANN-LEHMANN, R. ET AL. Reassessment of feline leukaemia virus (FeLV) vaccines with novel sensitive molecular assays. Vaccine, v.24, p.1087-1094, 2006. Disponível em: <http://www.sciencedirect.com>. Acesso em: 19 out. 2009. doi:10.1016/j.vaccine.2005.09.010.

HOFMANN-LEHMANN, R. ET AL. Vaccination against the feline leukaemia virus: outcome and response categories and long-term follow-up. Vaccine, v.25, p.5531-5539, 2007. Disponível em: <http://www.sciencedirect.com>. Acesso em: 19 out. 2009. doi:10.1016/j.vaccine.2006.12.022.

HOFMANN-LEHMANN, R. ET AL. How molecular methods change our views of FeLV infection and vaccination. Veterinary Immunology and Immunopathology, v.123, p.119-123, 2008. Disponível em: <http://www.elsevier.com/ locate/vetimm>. Acesso em: 19 out. 2009. doi:10.1016/ j.vetimm.2008.01.017.

HOOVER, E.A. et al. Relationship between feline leukemia virus antigen expression and viral infectivity in blood, bone marrow, and saliva of cats. Cancer Research, v.37, p.3707$3710,1977$.

HOOVER, E.A.; MULLINS, J.I. Feline leukemia virus infection and diseases. Journal of the American Veterinary Medical Association, v.199, p.1287-1297, 1991.

JACKSON, M.L. et al. Feline leukemia virus detection by ELISA and PCR in peripheral blood from 68 cats with high, moderate, or low suspicion of having FeLV-related disease. Journal of Veterinary Diagnostic Investigation, v.8, p.25$30,1996$.

JARRETT, W.F. et al. A virus-like particle associated with leukaemia (lymphosarcoma). Nature, v.202, p.567-568, 1964.

JARRETT, O. et al. Determinants of the host range of feline leukaemia viruses. Journal of General Virology, v.20, p.169$175,1973$.

JARRETT, O. et al. Interaction between feline leukaemia virus subgroups in the pathogenesis of erythroid hypoplasia. International Journal of Cancer, v.34 p.283-288, 1984.

LAFRADO, L.J. Evaluation of a feline leukemia virus vaccine in a controlled natural transmission study. Journal of the American Animal Hospital Association, v.204, p.914-917, 1994. 
LEVY, J.K. et al. Seroprevalence of feline leukemia virus and feline immunodeficiency virus infection among cats in North America and risk factors for seropositivity. Journal of American Veterinary Medical Association, v.228, n.3, p.371-376, 2006.

LEVY, J. et al. American Association of Feline Practitioners' feline retrovirus management guidelines Journal of Feline Medicine and Surgery, v.10, p.300-316, 2008. Disponível em: <http://www.catvets.com>. Acesso em: 19 out. 2009. doi: $10.1016 /$ j.jfms.2008.03.002.

LEWIS, M.G. et al. Protection against feline leukemia by vaccination with a subunit vaccine. Infection and Immunity, v.34, p.888-894, 1981.

LUTZ, H. et al. Detection of feline leukemia virus infection. Feline Practice, v.10, n.4, p.13-23, 1980.

LUTZ, H. et al. Course of feline leukemia virus infection and its detection by enzyme-linked immunosorbent assay and monoclonal antibodies. American Journal of Veterinary Research, v.44, p.2054-2059, 1983.

LUTZ, H. et al. Feline Leukaemia ABCD guidelines on prevention and management. Journal of Feline Medicine and Surgery, v.11, p.565-574, 2009. Disponível em: <http:/ /www.abcd-vets.org>. Acesso em: 19 out. 2009. doi:10.1016/ j.jfms.2009.05.005.

MADEWELL, B.R.; JARRETT, O. RECovery of feline leukaemia virus from nonviraemic cats. Veterinary Research, v.112, p.339-342, 1983.

MEINERZ, A.R.M. et al. Frequência do virus da leucemia felina (VLFe) em felinos domésticos (Felis catus) semidomiciliados nos municípios de Pelotas e Rio Grande. Ciência Animal Brasileira, v.11, n.1, p.90-93, 2010.

MENDOZA, R. et al. A putative thiamine transport protein is a receptor for feline leukemia virus subgroup A. Journal of Virology, v.80, p.3378-3385, 2006. Disponível em: <http:// www.jvi.asm.org>. Acesso em: 07 ago. 2007. doi:10.1128/ JVI.80.7.3378-3385.2006.

MOSER, M. et al. The host range and interference properties of two closely related feline leukemia variants suggest that they use distinct receptors. Virology, v.242, p.366-377, 1998.

OVERBAUGH, J.; BANGHAM, C.R.M. Selection forces and constraints on retroviral sequence variation. Science, v.292, p.1106-1109, 2001. Disponível em: 〈http://www.sciencemag.org〉. Acesso em: 11 maio, 2010. doi: 10.1126/science.1059128.

PEDERSEN, N.C. et al. The clinical significance of latent feline leukemia virus infection in cats. Feline Practice, v.14, p.32-48, 1984.

ROJKO, J.L. et al. Pathogenesis of experimental feline leukemia virus infection. Journal of the National Cancer Institute, v.63, p.759-768, 1979.

SOUZA, H.J.M. et al. Estudo epidemiológico de infecções pelo vírus da leucemia e/ou imunodeficiência felina, em gatos domésticos do município do Rio de Janeiro. Clínica Veterinária, v.36, p.14-21, 2002.

SPARKES, A.H. Feline leukemia virus: a review of immunity and vaccination. Journal of Small Animal Practice, v.38, p.187-194, 1997.

STEWART, M.A. et al. Nucleotide sequences of a feline leukemia virus subgroup A envelope gene and long terminal repeat and evidence for the recombinational origin of subgroup B viruses. Journal of Virology, v.58, p.825-834, 1986.

TANDON, R. et al. Quantitation of feline leukaemia virus and proviral loads by TaqMan real time polymerase chain reaction. Journal of Virological Methods, v.130, p.124-132, 2005. Disponível em: 〈http://www.elsevier.com/locate/jviromet>. Acesso em: 19 out. 2009. doi:10.1016/j.jviromet.2005.06.017.

TEIXEIRA, B.M. et al. Ocorrência do vírus da imunodeficiência felina e do vírus da leucemia felina em gatos domésticos mantidos em abrigos no município de Belo Horizonte. Arquivo Brasileiro de Medicina Veterinária e Zootecnia, v.59, n.4, p.939-947, 2007.

TIZZARD, I.; BASS, E.P. Evaluation of a killed, whole vírion feline leukemia virus vaccine. Journal of the American Veterinary Medical Association, v.199, p.1410-1413, 1991.

TORRES, A.N. et al. Re-examination of feline leukemia virus: host relationships using real-time PCR. Virology, v.332, p.272283, 2005. Disponível em: 〈http://www.elsevier.com/locate/yviro〉. Acesso em: 25 out. 2009. doi:10.1016/j.virol.2004.10.050.

TORRES, A.N. et al. Feline leukemia virus immunity induced by whole inactivated virus vaccination. Veterinary Immunology Immunopathology, v.134, p.122-131, 2010. Disponível em: <http://www.elsevier.com/locate/vetimm>. Acesso em: 11 maio, 2010. doi: 10.1016/j.vetimm.2009.10.017. 